\title{
PENGEMBANGAN MODUL ELEKTRONIK FISIKA BERBASIS KETERAMPILAN PROSES SAINS UNTUK MENINGKATKAN KEMAMPUAN BERPIKIR KRITIS DAN MOTIVASI BELAJAR SISWA SMA/MA KELAS X PADA MATERI DINAMIKA GERAK
}

\author{
Fengky Adie Perdana ${ }^{1}$, Sarwanto $^{2}$, Sukarmin $^{3}$ \\ ${ }^{1}$ Program Studi Pendidikan Sains FKIP Universitas Sebelas Maret \\ Surakarta, 57126, Indonesia \\ fengkyadie@student.uns.ac.id. \\ ${ }^{2}$ Program Studi Pendidikan Sains FKIP Universitas Sebelas Maret \\ Surakarta, 57126, Indonesia \\ sarwanto@staff.fkip.uns.ac.id \\ ${ }^{3}$ Program Studi Pendidikan Sains FKIP Universitas Sebelas Maret \\ Surakarta, 57126, Indonesia \\ sukarmin67@staff.fkip.uns.ac.id
}

\begin{abstract}
Abstrak
Pembelajaran Fisika yang di terapkan di SMA Warga Surakarta belum mengarahkan siswa pada pembelajaran berbasis keterampilan proses dan cenderung teacher centered. Penelitian ini bertujuan untuk merancang dan menyusun modul elektronik pembelajaran Fisika berbasis keterampilan proses sains, serta menguji efektivitas modul terhadap kemampuan berpikir kritis dan motivasi belajar siswa. Metode penelitian dan pengembangan yang digunakan Research and Development (R\&D). Model penelitian dan pengembangan menggunakan model penelitian 4D Thiagarajan. Modul Fisika dikembangkan menggunakan pendekatan keterampilan proses sains dengan langkah: mengamati, merumuskan masalah, merumuskan hipotesis, mengidentifikasi variabel, melakukan eksperimen, menganalisis data, menyimpulkan dan mengomunikasikan. Instrumen yang digunakan dalam penelitian ini adalah angket, lembar validasi, lembar observasi dan soal pretest\&post test. Analisis hasil angket, kelayakan modul dan hasil observasi dianalisis dengan diskriptif kualitatif berdasarkan skor kriteria. Analisis kemampuan berpikir kritis diuji dengan program SPSS dengan uji parametrik sampel berpasangan, sedangkan motivasi belajar dianalisis menggunakan uji non parametrik Mann Whitney. Hasil penelitian menunjukkan bahwa: 1) modul elektronik telah dikembangkan dengan mengintegrasikan keterampilan proses sains untuk meningkatkan kemampuan berpikir kritis dan motivasi belajar siswa. 2) Modul elektronik Fisika berbasis keterampilan proses sains memenuhi kriteria sangat baik, dilihat dari hasil validasi materi, media, validasi praktisi pendidikan dan teman sejawat, dengan nilai rata-rata 3,80 lebih besar dari nilai minimum kelayakan 3,78. 3) efektivitas modul berbasis keterampilan proses sains didapatkan nilai $\mathrm{N}$-gain dari uji coba besar 0,67 pada kelas sampel dan 0,59 pada kelas kontrol yang dikategorikan "sedang". 4) Implementasi modul elektronik Fisika berbasis keterampilan proses sains ini dinilai efektif meningkatkan motivasi belajar siswa. Hasil uji statistik menunjukkan nilai signifikansi sebesar 0,027 lebih rendah dari taraf signifikansi $\alpha=0,05$, hal ini berarti bahwa terdapat perbedaan yang signifikan antara motivasi belajar kelas sampel dan kelas kontrol. Sehingga dapat disimpulkan bahwa motivasi belajar siswa menggunakan modul Fisika berbasis keterampilan proses sains lebih baik dari pembelajaran konvensional
\end{abstract}

Kata Kunci: Modul elektronik, Keterampilan Proses Sains, Kemampuan Berpikir Kritis, Motivasi Belajar Siswa

\section{Pendahuluan}

Permendiknas No.19 tahun 2005 tentang Standar Nasional Pendidikan (SNP) menjelaskan bahwa proses pembelajaran pada satuan pendidikan diselenggarakan secara interaktif, inspiratif, menyenangkan, menantang, memotivasi peserta didik untuk berpartisipasi aktif, serta memberikan ruang yang cukup bagi prakarsa, kreativitas, dan kemandirian sesuai dengan bakat, minat, dan perkembangan fisik serta psikologis peserta 
didik. Oleh karena itu proses pembelajaran harus dirancang, dilaksanakan guru sebagai pendidik dapat memenuhi amanat peraturan pemerintah tersebut.

Seiring dengan kompleknya permasalahan pada kegiatan pembelajaran di kelas, kompetensi yang dimiliki siswa tidak terbatas pada keterampilan proses, tetapi perlu memiliki kemampuan berpikir untuk menghadapi berbagai persoalan yang ada di dalam kegiatan pembelajaran, dalam hal ini kemampuan berpikir kritis perlu adanya penekanan. Sejalan dengan pengembangan kemampuan berpikir kritis, pemerintah melalui Peraturan Pemerintah No. 32 tahun 2013 pasal 77 I ayat I menjelaskan bahwa bahan kajian ilmu pengetahuan alam, antara lain, Fisika, Biologi, dan Kimia dimaksudkan untuk mengembangkan pengetahuan, pemahaman, dan kemampuan analisis peserta didik terhadap lingkungan alam dan sekitarnya" dari pernyataan tersebut jelas bahwa pembelajaran Fisika dimaksudkan untuk memperoleh kompetensi lanjut akan ilmu pengetahuan dan teknologi serta membudayakan berpikir ilmiah secara kritis, kreatif, dan mandiri.

Berdasarkan hasil observasi di SMA Warga Surakarta yang ditunjukkan pada Tabel 1, diketahui bahwa dalam melaksanakan kegiatan belajar mengajar guru sudah menggunakan modul rangkuman sendiri untuk membelajarkan materi Fisika. Guru mata pelajaran Fisika juga sudah menggunakan pendekatan keterampilan proses dalam membelajarkan Fisika. Pendekatan keterampilan proses sains dianggap sangat penting oleh guru, karena dinilai akan lebih memberikan kesan mendalam pada siswa. Terdapat beberapa tahapan keterampilan proses sains yang belum sering diterapkan oleh guru, salah satunya adalah tahapan mengklasifikasikan. Menurut hasil angket analisis guru, siswa kelas X MIA di SMA Warga pada umumnya memiliki kemampuan sedang dalam hal merubah data menjadi grafik, memiliki kemampuan rendah dalam hal merubah grafik menjadi persamaan, selain itu memiliki kemampuan rendah dalam hal melakukan analisis grafik dan data.
Hasil wawancara dengan guru, memperoleh informasi tentang modul yang diinginkan guru, yaitu: 1) isi modul sesuai dengan kurikulum yang berlaku; 2) bahan ajar yang digunakan dapat melatih siswa untuk membangun dan menemukan pengetahuannya sendiri; 3) siswa dapat terlibat penuh dalam kegiatan pembelajaran yang berlangsung; 4) praktis dan komunikatif; 5) terdapat kegiatan praktikum/demonstrasi yang sesuai dengan materi; 6) terdapat tugas/soal latihan yang dapat meningkatkan kemampuan berpikir kritis siswa; 7) materi pelajaran yang disampaikan dapat menarik minat siswa, singkat, jelas dan mudah dipahami; 8) terdapat video aplikasi dalam kehidupan sehari-hari.

Tabel 1. Analisis Kebutuhan Siswa Kelas X SMA Warga Surakarta

\begin{tabular}{|c|c|c|c|}
\hline \multirow{2}{*}{ No } & \multirow{2}{*}{ Aspek Yang Diamati } & \multicolumn{2}{|c|}{ Persentase $(\%)$} \\
\hline & & Ya & Tidak \\
\hline 1. & $\begin{array}{l}\text { Siswa memiliki buku pelajaran } \\
\text { Fisika }\end{array}$ & $86 \%$ & $14 \%$ \\
\hline 2. & $\begin{array}{l}\text { Bapak/ibu guru mengunakan } \\
\text { bahan ajar khusus }\end{array}$ & $100 \%$ & $0 \%$ \\
\hline 3. & $\begin{array}{l}\text { Siswa mencari sumber lain } \\
\text { untuk mempelajari materi }\end{array}$ & $79 \%$ & $21 \%$ \\
\hline 4. & $\begin{array}{l}\text { Siswa bisa merubah data dalam } \\
\text { bentuk tabel ke dalam bentuk } \\
\text { grafik }\end{array}$ & $48 \%$ & $41 \%$ \\
\hline 5. & $\begin{array}{l}\text { Siswa bisa merubah data dalam } \\
\text { bentuk grafik kedalam bentuk } \\
\text { persamaan }\end{array}$ & $41 \%$ & $59 \%$ \\
\hline \multirow[t]{5}{*}{6.} & Siswa membutuhkan bahan ajar & $97 \%$ & $3 \%$ \\
\hline & alternatif yang dapat digunakan & & \\
\hline & untuk mempelajari konsep & & \\
\hline & $\begin{array}{l}\text { Fisika secara lebih mudah dan } \\
\text { menarik }\end{array}$ & & \\
\hline & & Sering & $\begin{array}{l}\text { Tidak } \\
\text { Pernah }\end{array}$ \\
\hline 7. & $\begin{array}{l}\text { Siswa sering mengajukan } \\
\text { pertanyaan kepada guru jika } \\
\text { diberi kesempatan untuk } \\
\text { bertanya }\end{array}$ & $59 \%$ & $41 \%$ \\
\hline 8. & $\begin{array}{l}\text { Siswa berani mengungkapkan } \\
\text { ide baru kepada guru atau } \\
\text { teman }\end{array}$ & $28 \%$ & $72 \%$ \\
\hline 9. & $\begin{array}{l}\text { Siswa sering mengalami } \\
\text { kesulitan mempelajari konsep } \\
\text { Fisika dari buku sumber yang } \\
\text { di gunakan }\end{array}$ & $66 \%$ & $34 \%$ \\
\hline
\end{tabular}

Menurut Briggs cit. Arif et al. (2010: 6), media adalah segala alat fisik yang dapat menyajikan pesan serta merangsang siswa untuk belajar. Contohnya adalah buku, film, kaset, film bingkai. Salah satu media ajar yang dapat digunakan siswa untuk belajar mandiri adalah dalam bentuk modul. Modul merupakan bahan ajar yang dapat digunakan oleh siswa 
untuk belajar secara mandiri dengan bantuan seminimal mungkin dari orang lain (Yudhi Munadi, 2010: 99). Pendapat-pendapat tersebut menegaskan bahwa dalam proses pembelajaran dibutuhkan sebuah modul sebagai pelengkap dari buku pegangan siswa, dimana salah satu karakteristik dari sebuah media pembelajaran adalah menumbuhkan motivasi dan rasa ingin tahu siswa. Pengembangan modul pembelajaran ditujukan untuk belajar mandiri siswa, sehingga dengan adanya modul yang diberikan kepada siswa dapat membantu dalam memotivasi belajar dan meningkatkan hasil belajar siswa itu sendiri.

Modul elektronik merupakan sebuah bentuk penyajian bahan belajar mandiri yang disusun secara sistematis kedalam unit pembelajaran terkecil untuk mencapai tujuan pembelajaran tertentu yang disajikan ke dalam format elektronik yang di dalamnya terdapat animasi, audio, navigasi yang membuat pengguna lebih interaktif dengan program (Sugianto, 2013). Media elektronik yang dapat diakses oleh siswa mempunyai manfaat dan karakteristik yang berbeda-beda. Jika ditinjau dari manfaatnya media elektronik sendiri dapat menjadikan proses pembelajaran lebih menarik, interaktif, dapat dilakukan kapan dan dimana saja serta dapat meningkatkan kualitas pembelajaran (Wiyoko, 2014).

Pan et. al. (2010: 151) menyatakan bahwa motivasi adalah ketika alasan satusatunya untuk memperoleh sesuatu diluar aktivitas itu sendiri, seperti lulus ujian. Dalam penelitian ini dikembangan modul pembelajaran yang salah satu karakteristik dari modul itu sendiri adalah memotivasi belajar siswa. Motivasi yang ditimbulkan oleh modul pembelajaran ini termasuk dalam motivasi ekstrinsik. Motivasi ekstrinsik menurut Sardiman (2012: 90) adalah motif-motif yang aktif dan berfungsinya karena adanya perangsang dari luar. Pendapat tersebut menjelaskan bahwa motivasi yang berasal dari luar diri siswa adalah motivasi ekstrinsik, sehingga motivasi yang ditimbulkan oleh adanya modul pembelajaran ini termasuk motivasi ekstrinsik. Motivasi yang berasal dari modul ini akan menimbulkan rasa ingin tahu dan minat belajar siswa meningkat. Ketika rasa ingin tahu dan minat belajar siswa meningkat maka aktivitas belajar siswa juga akan berbanding lurus. Aktivitas siswa akan meningkat seiring termotivasinya siswa dengan penggunakan modul yang dikembangkan, sehingga hasil belajarnya pun akan meningkat.

Sardiman (2008:75) mendefinisikan motivasi sebagai keseluruhan daya penggerak di dalam diri siswa yang menimbulkan kegiatan belajar, yang menjamin kelangsungan dari kegiatan belajar yang memberikan arah pada kegiatan belajar, sehingga tujuan yang dikehendaki oleh subjek belajar itu dapat tercapai. Motivasi adalah perubahan dalam diri atau pribadi seseorang yang ditandai dengan timbulnya perasaan dan reaksi untuk mencapai tujuan. Sebelum dilakukan proses pengembangan, siswa diberi angket motivasi sebanyak 40 butir pernyataan untuk mengukur motivasi belajar siswa, serta dilakukan observasi sebagai data pendukung dari pengisian angket motivasi siswa tersebut. (Sardiman, 2011: 83) mengemukakan bahwa ciri-ciri orang yang bermotivasi ada 8 aspek. Hasil observasi awal motivasi belajar siswa yang ditunjukkan pada Tabel 2 menggunakan skala likert dapat diketahui bahwa kondisi awal motivasi belajar siswa masih perlu ditingkatkan. Terbukti bahwa siswa masih cepat bosan terhadap tugas rutin yang dijalani, senang bekerja secara mandiri, kurang dapat mempertahankan pendapat dan kurang senang mencari dan memecahkan masalah soal.

Tabel 2. Observasi Awal Motivasi Belajar Siswa

\begin{tabular}{llc}
\hline No & Aspek Motivasi & Rerata \\
\hline 1. & Tekun dalam menghadapi tugas & 3.36 \\
2. & Ulet dalam menghadapi kesulitan & 3.24 \\
3. & Menunjukkan minat & 3.35 \\
4. & Senang bekerja mandiri & 2.95 \\
5. & Cepat bosan pada tugas rutin & 1.70 \\
6. & Dapat mempertahankan pendapatnya & 2.88 \\
7. & Tidak mudah melepas hal yang diyakini & 3.28 \\
8. & Senang mencari dan memecahkan masalah & 2.84 \\
& soal-soal \\
\hline
\end{tabular}

Salah satu solusi yang ditawarkan adalah dengan mengembangkan modul elektronik Fisika berbasis keterampilan proses sains. Melalui modul elektronik ini, siswa diharapkan mampu mengamati, merumuskan masalah, merumuskan hipotesis, 
mengidentifikasi variabel, melakukan percobaan, menganalisis data, menyimpulkan dan mengomunikasikan dalam proses pembelajaran untuk membuktikan suatu konsep, sehingga akan meningkatkan motivasi belajar dan meningkatkan kemampuan berpikir kritis siswa. Proses pembelajaran idealnya dapat melibatkan siswa secara aktif, dan pendekatan pembelajaran yang inovatif itu berpusat pada siswa (student centered) terkait dengan permasalahan dalam kehidupan seharihari.

Penerapan kurikulum 2013 menuntut guru untuk meningkatkan keaktifan siswa dalam proses pembelajaran. Aydinli (2011) menyatakan bahwa kurikulum menyarankan bahwa banyak aktivitas sains membutuhkan keterampilan proses sains dengan mengharapkan guru menggunakan strategi pembelajaran inkuiri. Kurikulum 2013 menekankan pada aktivitas siswa, sehingga pengembangan modul adalah salah satu pendukung dari keterlaksanaan kurikulum 2013.

Dengan pengembangan modul elektronik Fisika berbasis keterampilan proses sains ini, siswa diharapkan mampu mengembangkan keterampilan-keterampilan berupa mengamati, merumuskan masalah, merumuskan hipotesis, identifikasi variable, melakukan percobaan, analisis data, menyimpulkan dan mengomunikasikan dalam proses proses pembelajaan untuk membuktikan suatu konsep, dengan begitu siswa akan berperan aktif dan tertarik sehingga motivasi belajarnya akan meningkat, begitu pula dengan kemampuan berpikir kritisnya. Padilla cit. Keil (2009) bahwa keterampilan sebagai kemampuan dipindahtangankan, sesuai dengan berbagai disiplin ilmu, dan mencerminkan perilaku ilmuwan serta menekankan bahwa proses ilmiah meliputi keterampilan baik dasar dan terintegrasi. Rauf (2013) menyatakan bahwa di dalam sains, keterampilan proses sains dasar membantu anak-anak untuk mengembangkan pembelajaran mereka melalui pengalaman. Kemudian Dimyati dan Mudjiono (2013: 140) menjelaskan bahwa keterampilan dasar terdiri dari enam keterampilan, yakni: mengobservasi, mengklasifikasi, memprediksi, mengukur, menyimpulkan, dan mengomunikasikan. Sesuai pendapat-pendapat tersebut, setiap siswa harus memiliki keterampilan-keterampilan dasar dalam pembelajaran Fisika, sehingga keterampilan proses sains tersebut dikemas dalam modul pembelajaran yang nantinya dapat membantu siswa mengembangkan keterampilan proses sainsnya secara mandiri.

Penelitian ini bertujuan untuk merancang dan menyusun modul pembelajaran Fisika berbasis keterampilan proses sains, serta menguji efektivitas modul terhadap kemampuan berpikir kritis dan motivasi belajar siswa.

\section{Metode Penelitian}

Penelitian ini dilakukan pada bulan April 2015 sampai dengan bulan Desember 2015. Metode dan rancangan penelitian menggunakan desain Research and Development (R\&D) dari Thiagarajan dan Sammel (1974), dengan langkah: pendefinisian (define), perancangan (design), pengembangan (develop), dan penyebaran (disseminate). Secara garis besar, instrumen pengumpulan data dalam penelitian ini antara lain berupa: angket, kuesioner, lembar validasi, soal tes, dan lembar observasi. Instrumen penelitian merupakan alat atau fasilitas yang digunakan oleh peneliti dalam mengumpulkan data agar hasilnya lebih baik, dalam arti lebih cermat, lengkap, dan sistematis sehingga lebih mudah diolah (Suharsimi, 2010: 265). Langkahlangkah yang dilakukan dalam penelitian pengembangan ini adalah sebagai berikut:

1. Tahap pendefinisian (define) merupakan tahap peneliti mengidentifikasi masalah pada keterlaksanaan kegiatan pembelajaran Fisika pada kelas $\mathrm{X}$ SMA Warga Surakarta. Identifikasi potensi dan masalah khususnya pada pembelajaran Fisika. Instrumen yang digunakan dalam tahap ini adalah angket untuk mengetahui kebutuhan siswa dan guru. Analisis yang digunakan adalah analisis 
kualitatif berdasarkan hasil angket yang diperoleh.

2. Tahap perancangan (design), pada tahap ini peneliti merancang modul elektronik pembelajaran Fisika berbasis keterampilan proses sains untuk meningkatkan kemampuan berfikir kritis dan motivasi belajar siswa. Pada tahap ini dirancang desain modul yang terdiri dari pendahuluan, isi dan penutup. Pada tahap ini dirancang matrik yang mengintegrasikan modul elektronik berbasis keterampilan proses sains dengan aspek kemampuan berfikir kritis dan motivasi belajar.

3. Tahap pengembangan (develop) merupakan tahap pengembangan modul untuk menghasilkan modul dan mengetahui tingkat kefektifan modul dalam pembelajaran. Dalam tahap pengembangan, instrumen yang digunakan terdiri dari: 1) angket validasi yang terdiri dari validasi ahli materi, validasi ahli media, praktisi pendidikan dan teman sejawat, 2) lembar observasi yang terdiri dari lembar observasi afektif, lembar observasi psikomotorik, lembar observasi keterampilan proses sains, lembar observasi kemampuan berfikir kritis, dan lembar observasi motivasi belajar siswa, 3) soal test berfikir kritis. Data yang diperoleh dari angket validasi dan lembar observasi di analisis dengan analisis diskriptif kualitatif. Data hasil belajar siswa berupa test kognitif yang berupa kemampuan berfikir kritis dianalisis menggunakan program SPSS dengan analisis uji parametrik sampel berpasangan. Sedangkan motivasi belajar siswa yang didapatkan dari lembar observasi pada saat proses pembelajaran juga diuji melalui program SPSS dengan analisis uji Mann Whitney.
4. Tahap penyebaran (disseminate) merupakan merupakan tahap akhir pengembangan. Tahap penyebaran dilakukan untuk mendapatkan masukan, koreksi, saran, penilaian, untuk menyempurnakan produk akhir pengembangan agar siap diadopsi oleh para guru SMA/MA di Surakarta. Instrumen yang digunakan dalam tahap ini adalah lembar angket kemudian dianalisis secara diskriptif kualitatif.

\section{Hasil Penelitian dan Pembahasan}

Hasil penelitian dan pengembangan, yaitu berupa modul elektronik Fisika berbasis keterampilan proses sains untuk meningkatkan kemampuan berpikir kritis dan motivasi belajar siswa. Kajian pembelajaran yang dikembangkan sesuai dengan Kurikulum 2013 pada KD 5.1 merencanakan dan melaksanakan percobaan untuk menyelidiki hubungan gaya, massa, dan percepatan dalam gerak lurus. Data hasil dari tahap hasil validasi ahli materi dapat dilihat pada Tabel 3 .

Tabel 3. Hasil Validasi Ahli Materi

\begin{tabular}{llll}
\hline No. & Aspek & Rata-rata & Kategori \\
\hline 1. & Kelayakan isi & 3,78 & Sangat baik \\
2. & Kelayakan bahasa & 4,00 & Sangat baik \\
3. & Kelayakan penyajian & 3,79 & Sangat baik \\
\hline Rata - rata & 3,85 & Sangat baik
\end{tabular}

Hasil validasi ahli media mengasilkan nilai rata-rata 3,84, seperti yang ditunjukkan pada Tabel 4.

Tabel 4. Hasil Validasi Ahli Media

\begin{tabular}{llll}
\hline No. & Aspek & Rata-rata & Kategori \\
\hline 1. & Ukuran fisik modul & 4,00 & Sangat baik \\
2. & Tata letak cover modul & 3,67 & Sangat baik \\
3. & Tipografi cover modul & 4,00 & Sangat baik \\
4. & Ilustrasi Kover Modul & 3,34 & Sangat baik \\
5. & Tata Letak Isi Modul & 3,93 & Sangat baik \\
6. & Tipografi Isi Modul & 4,00 & Sangat baik \\
7. & Ilustrasi Isi Modul & 4,00 & Sangat baik \\
\hline \multicolumn{2}{l}{ Rata - rata } & 3,84 & Sangat baik \\
\hline
\end{tabular}

Hasil validasi praktisi pendidikan mengasilkan nilai rata-rata 3,78 , seperti yang ditunjukkan pada Tabel 5.

Tabel 5. Hasil Validasi Praktisi Pendidikan

\begin{tabular}{llll}
\hline No. & Aspek & Rata-rati & Kategori \\
\hline 1. & Aspek Isi & 3,75 & Sangat baik \\
2. & Aspek Metode Penyajian & 3,75 & Sangat baik \\
\hline
\end{tabular}




\begin{tabular}{llll}
\hline No. & Aspek & Rata-rat: & Kategori \\
\hline 3. & Aspek Bahasa & 4,00 & Sangat baik \\
4. & Aspek Ilustrasi & 3,75 & Sangat baik \\
5. & Aspek Kelengkapan & 3,75 & Sangat baik \\
6. & Aspek Fisik & 3,50 & Sangat baik \\
7. & Aspek Keterlaksanaan & 4,00 & Sangat baik \\
\hline Rata - Rata & 3,78 & Sangat baik \\
\hline
\end{tabular}

Hasil validasi teman sejawat mengasilkan nilai rata-rata 3,72, seperti yang ditunjukkan pada Tabel 6.

Tabel 6. Hasil Validasi Teman Sejawat

\begin{tabular}{llcl}
\hline No. & Aspek & Rata-rata & Kategori \\
\hline 1. & Aspek Isi & 3,67 & Sangat baik \\
2. & Aspek Metode Penyajian & 3,75 & Sangat baik \\
3. & Aspek Bahasa & 3,65 & Sangat baik \\
4. & Aspek Ilustrasi & 3,50 & Sangat baik \\
5. & Aspek Kelengkapan & 3,75 & Sangat baik \\
6. & Aspek Fisik & 4,00 & Sangat baik \\
7. & Aspek Keterlaksanaan & 3,75 & Sangat baik \\
\hline \multicolumn{2}{l}{ Rata - rata } & 3,72 & Sangat baik \\
\hline
\end{tabular}

Hasil rekap uji validasi modul ditunjukkan pada Gambar 1.

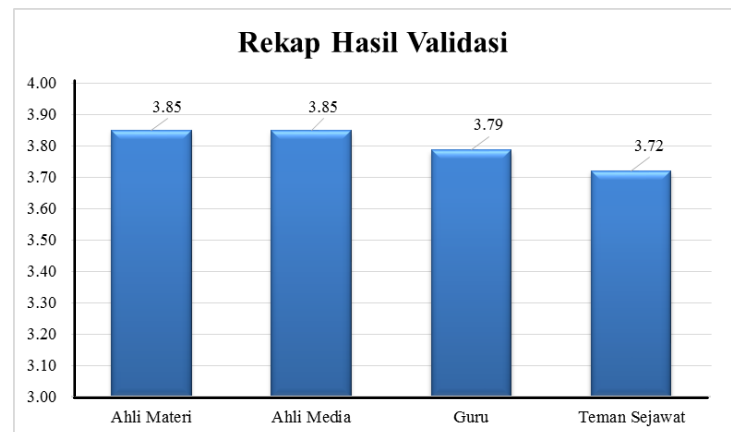

Gambar 1. Histogram Hasil Validasi Ahli, Praktisi dan Teman Sejawat

Setelah revisi berdasarkan saran dan masukan dari masing-masing validator selesai dilaksanakan, maka tahap selanjutnya adalah uji kecil. Uji kecil ini dilakukan untuk mengetahui tingkat keterbacaan modul. Hasil tanggapan siswa dari uji kecil ditunjukkan pada Tabel 7.

\section{Tabel 7. Hasil Uji Kecil}

\begin{tabular}{lll}
\hline No & $\begin{array}{l}\text { Kegiatan } \\
\text { Belajar }\end{array}$ & \multicolumn{1}{c}{ Tanggapan } \\
\hline 1 & $\begin{array}{l}\text { Kegiatan } \\
\text { belajar I }\end{array}$ & $\begin{array}{l}\text { 1. Masih terdapat pertanyaan yang } \\
\text { membingungkan siswa } \\
\text { 2. Penambahan ilustrasi gambar pada } \\
\text { soal evaluasi\&diskusi }\end{array}$ \\
& & $\begin{array}{l}\text { 3. Siswa butuh soal arahan untuk } \\
\text { menarik kesimpulan }\end{array}$ \\
& & $\begin{array}{l}\text { 1. Pada lembar identifikasi variable, } \\
\text { kata "jawaban" lebih baik diganti } \\
\text { dengan "hipotesis", supaya sesuai }\end{array}$
\end{tabular}

dengan perintah sebelumnya

2. Lebih diberi penjelasan pada kegiatan praktikum

3. Penambahan ilustrasi gambar pada soal diskusi

3 Kegiatan 1. Terdapat kalimat perintah yang belajar III kurang sesuai

2. Perbaikan pada tabel analisis data

3. Penambahan ilustrasi gambar pada contoh soal dan diskusi

Setelah dilakukan uji kecil, langkah selanjutnya adalah dilakukan proses uji besar. Dalam uji besar, data yang didapat adalah hasil belajar kognitif, hasil belajar afektif, hasil belajar psikomotor, hasil keterampilan proses sains, hasil kemampuan berpikir kritis, motivasi belajar siswa dan hasil respon siswa terhadap modul. Data hasil belajar kognitif siswa kelas sampel dan kelas kontrol ditunjukkan pada Tabel 8 dan Tabel 9.

Tabel 8. Deskripsi Data Hasil Belajar Kognitif Siswa Kelas Sampel

\begin{tabular}{llllll}
\hline $\begin{array}{l}\text { Jenis } \\
\text { Tes }\end{array}$ & $\begin{array}{l}\text { Jml. } \\
\text { Siswa }\end{array}$ & Mean & Std Dev & $\begin{array}{l}\text { Nilai } \\
\text { Min }\end{array}$ & $\begin{array}{l}\text { Nilai } \\
\text { Maks }\end{array}$ \\
\hline Pretest & 29 & 35,7 & 9,588 & 15 & 60 \\
Posttest & 29 & 81,37 & 6,322 & 65 & 90 \\
\hline
\end{tabular}

Tabel 9. Deskripsi Data Hasil Belajar Kognitif Siswa Kelas Kontrol

\begin{tabular}{|c|c|c|c|c|c|}
\hline Jenis Tes & $\begin{array}{l}\text { Jml. } \\
\text { Siswa }\end{array}$ & Mean & $\begin{array}{l}\text { Std } \\
\text { Dev }\end{array}$ & $\begin{array}{l}\text { Nilai } \\
\text { Min }\end{array}$ & $\begin{array}{l}\text { Nilai } \\
\text { Maks }\end{array}$ \\
\hline Pretest & 28 & 36,61 & 9,335 & 15 & 55 \\
\hline Posttest & 28 & 79,96 & 6,432 & 65 & 90 \\
\hline
\end{tabular}

Hasil observasi keterampilan proses sains mengasilkan nilai rata-rata 81,58, seperti yang ditunjukkan pada Tabel 10 .

Tabel 10. Hasil Observasi Keterampilan Proses

\begin{tabular}{|c|c|c|c|c|c|}
\hline \multirow{2}{*}{ Tahapan KPS } & \multicolumn{3}{|c|}{ Kegiatan Belajar } & \multirow{2}{*}{$\begin{array}{l}\text { Rata-rata } \\
(\%)\end{array}$} & \multirow{2}{*}{ Kategori } \\
\hline & $\mathrm{I}$ & II & III & & \\
\hline Mengamati & 63,33 & 78,75 & 90,00 & 77,36 & Sangat Baik \\
\hline $\begin{array}{l}\text { Merumuskan } \\
\text { Masalah }\end{array}$ & 67,50 & 83,75 & 89,17 & 80,13 & Sangat Baik \\
\hline $\begin{array}{l}\text { Merumuskan } \\
\text { Hipotesis }\end{array}$ & 73,75 & 86,67 & 90,00 & 83,47 & Sangat Baik \\
\hline $\begin{array}{l}\text { Identifikasi } \\
\text { Variabel }\end{array}$ & 58,75 & 75,00 & 82,92 & 72,22 & Baik \\
\hline Bereksperimen & 76,25 & 87,50 & 90,83 & 84,86 & Sangat Baik \\
\hline Analisis Data & 77,50 & 87,08 & 89,17 & 84,58 & Sangat Baik \\
\hline Menyimpulkan & 81,25 & 88,33 & 89,58 & 86,39 & Sangat Baik \\
\hline $\begin{array}{l}\text { Mengomunikasi } \\
\text { kan }\end{array}$ & 79,58 & 88,92 & 88,33 & 83,61 & Sangat Baik \\
\hline Rata-rata & 72,24 & 83,75 & 88,75 & 81,58 & Sangat Baik \\
\hline
\end{tabular}

Hasil observasi kemampuan berfikir kritis mengasilkan nilai rata-rata $85,61 \%$, seperti yang ditunjukkan pada Tabel 11 . 
Tabel 11. Hasil Kemampuan Berpikir Kritis

\begin{tabular}{rcccll}
\hline \multirow{2}{*}{ Observer } & \multicolumn{3}{c}{ Kegiatan Belajar } & \multicolumn{2}{l}{ Rata- } \\
\cline { 2 - 4 } rata(\%) & Kategori \\
\hline Observer 1 & 83,57 & 87,02 & 89,17 & 86,59 & Sangat Baik \\
Observer 2 & 79,04 & 86,42 & 88,45 & 84,64 & Sangat Baik \\
\hline Rata-rata & 81,30 & 86,72 & 88,80 & 85,61 & Sangat Baik \\
\hline
\end{tabular}

Hasil analisis motivasi belajar siswa mengalami peningkatan setelah dilakukan pembelajaran dengan menggunakan modul, seperti yang ditunjukkan pada Tabel 12 .

Tabel 12. Motivasi Belajar Siswa

\begin{tabular}{llll}
\hline No & Indikator & $\begin{array}{l}\text { Sebelum } \\
(\%)\end{array}$ & $\begin{array}{l}\text { Sesudah } \\
(\%)\end{array}$ \\
\hline 1 & $\begin{array}{l}\text { Tekun dalam } \\
\text { menghadapi tugas }\end{array}$ & 84,14 & 93,53 \\
2 & $\begin{array}{l}\text { Ulet dalam menghadapi } \\
\text { kesulitan }\end{array}$ & 81,03 & 94,83 \\
3 & Menunjukkan minat & 83,97 & 95,40 \\
4 & Senang bekerja mandiri & 73,79 & 94,83 \\
5 & $\begin{array}{l}\text { Cepat bosan pada tugas } \\
\text { rutin }\end{array}$ & 42,59 & 96,98 \\
6 & $\begin{array}{l}\text { Dapat mempertahankan } \\
\text { pendapatnya }\end{array}$ & 72,07 & 94,40 \\
7 & $\begin{array}{l}\text { Tidak mudah melepas } \\
\text { hal yang diyakini }\end{array}$ & 82,07 & 94,83 \\
8 & $\begin{array}{l}\text { Senang mencari dan } \\
\text { memecahkan masalah }\end{array}$ & 71,21 & 92,67 \\
& $\begin{array}{l}\text { soal-soal } \\
\quad \text { Rata-rata }\end{array}$ & 73,86 & 94,68 \\
\hline
\end{tabular}

Hasil penilaian modul setelah dilakukan uji besar mengasilkan nilai rata-rata 96,40\%, seperti yang ditunjukkan pada Tabel 13.

Tabel 13. Hasil Penilaian Modul pada Uji Besar

\begin{tabular}{llll}
\hline No. & Indikator & Rata-rata $(\%)$ & Kategori \\
\hline 1. & Perhatian & 96,45 & Sangat Baik \\
2. & Keterkaitan & 95,00 & Sangat Baik \\
3. & Keyakinan & 98,12 & Sangat Baik \\
4. & Kepuasan & 96,04 & Sangat Baik \\
\hline \multicolumn{2}{l}{ Rata-rata } & 96,40 & Sangat Baik
\end{tabular}

Tahapan terakhir setelah dilakukan uji coba besar adalah tahap disseminasi dan implementasi produk pada SMA/MA di kota Surakarta. Hasil dari tahap diseminasi ditunjukkan pada Tabel 14.

Tabel 14. Hasil Kuesioner Tahapan Diseminasi dan Implementasi Produk

\begin{tabular}{llll}
\hline No. & Aspek & Rata-rata $(\%)$ & Kategori \\
\hline 1. & Isi Modul & 3,93 & Sangat Baik \\
2. & Metode Penyajian & 4,00 & Sangat Baik \\
3. & Bahasa & 4,00 & Sangat Baik \\
4. & Ilustrasi & 4,00 & Sangat Baik \\
5. & Kelengkapan & 4,00 & Sangat Baik \\
6. & Fisik & 4,00 & Sangat Baik \\
7. & Keterlaksanaan & 3,50 & Sangat Baik \\
\hline \multicolumn{2}{l}{ Rata-rata } & 3,92 & Sangat Baik \\
\hline
\end{tabular}

\section{Pembahasan}

\section{Tahap Pendefinisian (Define)}

Tahap pendefinisian ini merupakan tahapan yang dilakukan untuk mengidentifikasi masalah yang ada dalam proses pembelajaran dan menjadi dasar untuk merancang produk berupa modul. Pada tahapan ini dilakukan analisis pada siswa, materi dan kurikulum yang sudah berjalan di SMA Warga Surakarta.

a. Pada tahap studi pustaka, SK dan KD dianalisis dan dipilih salah satu materi yang memungkinkan untuk digunakan sebagai acuan pengembangan modul pembelajaran. Analisis mengenai bahan ajar menunjukkan bahwa di sekolah masih menggunakan buku ajar yang terbatas, buku yang menunjang belajar siswa berupa modul rangkuman pembelajaran yang dibuat guru dan handout yang diterbitkan oleh Pusat Perbukuan Depdiknas, serta dalam proses pembelajaran siswa tidak melakukan kegiatan eksperimen. Sehingga keterampilan proses sains siswa belum bisa terlatih secara optimal.

b. Hasil Survei Lapangan meliputi kegiatan observasi, pemberian angket, dan wawancara kepada guru Fisika dan siswa, yaitu untuk pengambilan data mengenai pembelajaran di kelas. Dari hasil survei lapangan diperoleh data diantaranya: pembelajaran cenderung menggunakan metode ceramah, motivasi dan minat belajar siswa masih rendah, pembelajaran dengan percobaan masih jarang dilakukan sehingga pemahaman siswa mengenai materi kurang baik, sarana dan prasarana cukup baik tetapi jarang digunakan dalam proses pembelajaran, siswa membutuhkan bahan ajar alternatif yang dapat digunakan untuk mempelajari konsep Fisika secara lebih mudah dan menarik, dan siswa sering mengalami kesulitan mempelajari konsep Fisika dari buku sumber yang di gunakan.

\section{Tahap Perancangan (Desain)}

Hasil dari studi pendahuluan digunakan sebagai dasar tahap perencanaan, tahap perencanaan meliputi perencanaan awal bentuk akhir media, perencanaan template media, 
perencanaan penyajian materi, serta perencanaan menu akses dalam media. Tujuan Pembelajaran disesuaikan dengan Permendiknas Nomor 41 tahun 2007 tentang standar proses, yang didalamnya menggambarkan proses dan hasil belajar yang diharapkan dapat tercapai oleh siswa sesuai dengan kompetensi dasar, dikembangkan sesuai hakikat sains dan terdiri dari tujuan pembelajaran kognitif produk, kognitif proses, psikomotor, dan afektif.

Hasil tahap perencanaan sebagai berikut: a.Hasil draft berupa modul elektronik Fisika berbasis keterampilan proses sains untuk meningkatkan kemampuan berpikir kritis dan motivasi belajar siswa pada materi dinamika gerak. Modul terdiri dari 3 bagian yaitu pendahuluan, isi, dan penutup. Modul bersifat sistematis karena disusun secara runtut sehingga dapat memudahkan siswa dalam belajar.

b. Instrumen penelitian yang digunakan yaitu angket dan kuisioner, lembar validasi, lembar observasi untuk penilaian, soal try out uji coba dan evaluasi.

c.Try out soal kemampuan berpikir kritis dan kognitif dilakukan pada 29 siswa kelas XI-MIA 2 SMA Warga Surakarta. Analisis butir soal dilakukan dengan menggunakan software SPSS untuk mengetahui validitas dan reliabilitas soal. Dalam melakukan proses rekap skor terhadap jawaban siswa, setiap item soal hanya terdiri dari angka 1 untuk jawaban benar dan angka 0 untuk jawaban salah. Kesimpulan yang didapat 20 soal valid untuk digunakan sebagai tes kognitif dan untuk menguji kemampuan berpikir kritis siswa.

\section{Tahap Pengembangan (Develop)}

Uji coba produk awal yang dilakukan yaitu tahap validasi ahli, praktisi pendidikan dan teman sejawat. Validasi ahli dilakukan oleh ahli materi modul dan ahli media modul.
Validasi praktisi pendidikan dilakukan oleh dua guru Fisika. Validasi teman sejawat dilakukan oleh mahasiswa yang menempuh pendidikan magister dalam bidang keilmuan pendidikan Fisika. Penelitian yang dilakukan oleh Lidy Alimah (2013) dapat diketahui bahwa modul yang telah teruji kelayakannya mampu meningkatkan pemahaman siswa dan layak digunakan dalam pembelajaran Fisika.

Berdasarkan hasil validasi ahli materi yang ditunjukkan pada Tabel 3, diperoleh ratarata keseluruhan aspek sebesar 3,85 dan memiliki kategori "sangat baik". Aspek kelayakan isi dan kedalaman materi dan ketepatan ilustrasi mendapatkan nilai kurang dari 4 karena dinilai masih kurang menggambarkan ilustrasi dari materi yang disampaikan, sehingga perlu dilakukan revisi.

Berdasarkan hasil validasi ahli media yang ditunjukkan pada Tabel 4, diperoleh ratarata keseluruhan aspek 3,84 dan memiliki kategori "sangat baik". Aspek tata letak cover modul, ilustrasi cover modul, dan tata letak isi modul mendapat nilai kurang dari 4. Sehingga dilakukan revisi pada tampilan cover modul dan penulisan paragraf dalam modul.

Berdasarkan hasil validasi praktisi yang ditunjukkan pada Tabel 5, diperoleh rata-rata keseluruhan aspek 3,78 dan memiliki kategori "sangat baik". Aspek metode penyajian, ilustrasi, dan aspek fisik perlu dilakukan revisi. Karena menurut guru, perlu ada alokasi yg jelas pada tahapan-tahapan yang terdapat didalam modul. Revisi juga dilakukan pada gambar yang dimuat didalam modul.

Berdasarkan hasil validasi oleh teman sejawat pada Tabel 7, diperoleh rata-rata 3,67 untuk aspek isi. Terdapat 3 indikator dalam aspek isi yang mendapat nilai 3, diantaranya: 1) menekankan kemampuan berpikir kritis, 2) kedalaman materi sesuai dengan taraf berpikir siswa, dan 3) informasi yang dikemukakan mengikuti perkembangan zaman. Aspek yang kedua adalah metode penyajian menghasilkan nilai rata-rata sebesar 3,75. Dalam aspek ini terdapat 2 indikator yang mendapat nilai 3, yaitu memberikan pengalaman langsung dan mendorong siswa menyimpulkan konsep, hukum atau fakta. Hal ini karena terdapat beberapa kalimat dalam tabel yang perlu 
direvisi karena dapat memunculkan kebingungan siswa. Aspek ilustrasi menghasilkan nilai rata-rata sebesar 3,5. Indikator kesesuaian penempatan ilustrasi/gambar mendapatkan nilai 3. Jadi perlu dilakukan revisi modul agar isi lebih jelas dan modul dapat mudah digunakan oleh siswa.

Hasil rekap uji validasi seperti ditunjukkan Gambar 1. diperoleh rata-rata validasi modul yang dilakukan oleh ahli materi, ahli media, praktisi pendidikan (guru) dan teman sejawat. Validasi yang dilakukan pada ahli materi mendapatkan nilai rata-rata sebesar 3,85 yang memenuhi kriteria sangat baik. Hasil validasi yang dilakukan oleh ahli media menghasilkan rata-rata 3,85 yang memenuhi kriteria sangat baik. Hasil validasi pada praktisi pendidikan yang dilakukan pada 2 guru Fisika menghasilkan rata-rata 3,78 yang memenuhi kriteria sangat baik. Selain itu validasi yang dilakukan pada 2 teman sejawat juga menghasilkan rata-rata 3,72 yang memenuhi kriteria sangat baik pula. Dari beberapa hasil validasi tersebut, rata-rata hasil validasi dari keseluruhan validator sebesar 3,80 sehingga dapat disimpulkan bahwa modul telah memenuhi kriteria sangat baik

Revisi produk I berdasar validasi oleh para ahli dan praktisi yaitu didapatkan masukan atau saran untuk diadakan perbaikan sebelum diujikan pada uji coba kecil. Hasil saran dan masukan dari para ahli dan praktisi digunakan sebagai perbaikan pada materi, desain modul, dan perangkat, kemudian dilakukannya revisi dan selanjutnya produk modul akan digunakan pada uji coba kecil.

Uji coba kecil dilakukan oleh lima belas orang siswa. Hasil data yang diperoleh berupa tanggapan siswa terhadap modul yang tersaji pada Tabel 7. Data hasil tanggapan siswa pada uji coba kecil tersebut, kemudian dilakukan revisi sesuai dengan temuan siswa saat melakukan seluruh tahapan yang ada didalam modul, memperbaiki kalimat perintah dan kalimat arahan dalam modul dan dalam kegiatan praktikum. Setelah dilakukan revisi, maka selanjutnya dilaksanakan uji besar untuk menerapkan modul dalam pembelajaran.
Hasil saran dan masukan dari uji coba kecil lima belas siswa digunakan sebagai bahan perbaikan, setelah modul diperbaiki maka digunakan uji coba besar. Saran yang didapatkan sesuai dengan Tabel 7 , yaitu penambahan gambar ilustrasi pada beberapa soal evaluasi dan soal diskusi. Setelah dilakukan revisi, maka selanjutnya dilaksanakan uji besar untuk menerapkan modul dalam pembelajaran.

Uji coba besar dilakukan pada kelas XMIA 3 sebagai kelas sampel dan X-MIA 1 sebagai kelas kontrol. Pada kelas X-MIA 3 terdiri dari 29 siswa, sedangkan pada kelas kontrol X-MIA 1 terdiri dari 28 siswa. Data diperoleh tahap uji coba besar adalah data hasil belajar kognitif, afektif, psikomotor, respon siswa terhadap modul Fisika, hasil keterampilan proses sains, kemampuan berpikir kritis siswa serta motivasi belajar siswa.

Berdasarkan data hasil belajar kognitif siswa yang ditunjukkan pada Tabel 8, diketahui bahwa rata-rata hasil belajar kognitif siswa sebelum diterapkan pembelajaran menggunakan modul sebesar 35,7 dengan standar deviasi 9,58 dan nilai minimum yang didapatkan 15 , serta nilai maksimum 50 . Ratarata yang didapatkan berdasarkan hasil belajar kognitif siswa setelah diterapkannya pembelajaran menggunakan modul sebesar 81,37 dengan standar deviasi 6,32 dan didapatkan nilai minimum 65 , serta nilai maksimum 90.

Berdasarkan data hasil belajar kognitif siswa yang ditunjukkan pada Tabel 9, diketahui bahwa rata-rata hasil belajar kognitif siswa sebelum diterapkan pembelajaran sebesar 36,61 dengan standar deviasi 9,335 dan nilai minimum yang didapatkan 15 , serta nilai maksimum 55. Rata-rata yang didapatkan berdasarkan hasil belajar kognitif siswa setelah kegiatan pembelajaran sebesar 76,96 dengan standar deviasi 6,432 dan didapatkan nilai minimum 65, serta nilai maksimum 90.

Berdasarkan hasil nilai pretest dan posttest pada kelas sampel dan kelas kontrol, kemudian dapat digunakan untuk mengetahui efektivitas pembelajaran menggunakan penerapan modul dengan rumus $\mathrm{N}$-gain 
ternormalisasi. Hasil $\mathrm{N}$-gain ternormalisasi hasil belajar kognitif siswa diperoleh rata-rata sebesar 0,68. Menurut kriteria Hake (1998: 1) besaran capaian nilai tersebut menunjukkan bahwa hasil belajar kognitif siswa dikategorikan "sedang".

Berdasarkan ringkasan mengenai analisis nilai kognitif siswa, diketahui bahwa normalitas data yang diuji menggunakan Kolmogorov-Smirnov diperoleh taraf signifikasi sebesar 0,179 untuk nilai pretest dan 0,061 untuk nilai posttest. Kedua nilai pretest-posttest lebih besar dari $\alpha=0,05$, sehingga $\mathrm{H} 0$ diterima dan mempunyai arti nilai pretest-posttest berdistribusi normal. Berdasarkan hasil uji homogenitas dengan taraf signifikasi sebesar 0,908>0,05, sehingga H0 diterima dan berarti variasi setiap sampel sama (homogen).

Data nilai pretest-posttest berdistribusi normal dan homogen, sehingga selanjutnya akan dilakukan analisis menggunakan uji oneway ANOVA. Berdasarkan perhitungan diperoleh hasil $\mathrm{t}=-23,352$ dengan probabilitas sebesar 0,000 (p-value $<0,05$ ), sehingga $\mathrm{H}_{0}$ ditolak. Data menunjukkan bahwa terdapat perbedaan yang signifikan antara nilai hasil belajar kognitif sebelum diterapkan pembelajaran menggunakan modul dengan nilai hasil belajar kognitif setelah diterapkan pembelajaran menggunakan modul antara kelas sampel dan kelas kontrol. Sesuai dengan penelitian yang dilakukan oleh Ince (2010) yang menyatakan bahwa terdapat perbedaan yang signifikan dalam nilai akhir dari tes keterampilan proses antara mahasiswa kelompok eksperimen dan kontrol, karena siswa memperoleh keterampilan seperti penelitian, penemuan, berpikir ilmiah.

Penilaian hasil belajar afektif siswa selama proses pembelajaran dilakukan dengan penilaian menggunakan lembar observasi dinilai oleh dua observer. Berdasarkan data penilaian hasil belajar afektif siswa, diketahui bahwa pada kegiatan belajar I rata-rata hasil belajar afektif siswa sebesar $87,81 \%$, kegiatan belajar II sebesar 93,67 dan kegiatan belajar III sebesar 94,48\%. Dari data hasil observasi didapatkan bahwa hasil belajar afektif siswa selalu mengalami kenaikan pada tiap kegiatan belajarnya, dengan kategori "Sangat Baik". Yuliani (2012) dalam penelitiannya menyatakan bahwa terdapat interaksi pembelajaran dengan pendekatan keterampilan proses terhadap prestasi kognitif dan afektif siswa.

Uji coba kelompok besar menunjukkan peningkatan hasil belajar siswa ranah pengetahuan, keterampilan, dan sikap sesuai dengan hasil penelitian yang telah dilakukan oleh Hesbon E Abungu, Mark I dan Samuel W (2014) yang menyatakan bahwa keterampilan proses sains mampu memberikan perkembangan hasil yang signifikan pada pembelajaran. Penilaian hasil belajar psikomotor selama pembelajaran dilakukan dengan penilaian menggunakan lembar observasi yang dinilai dua orang observer. Berdasarkan hasil penilaian belajar psikomotor siswa, diketahui bahwa rata-rata hasil observasi psikomotor pada kegiatan pembelajaran I sebesar $84,13 \%$, pertemuan kedua sebesar $85,17 \%$ dan pertemuan ketiga sebesar 88,39\%. Dari hasil observasi juga didapatkan bahwa kemampuan psikomotor siswa tiap pertemuan mengalami kenaikan dengan kategori "Sangat Baik".

Penilaian keterampilan proses sains selama pembelajaran diambil dari penilaian menggunakan lembar observasi yang dinilai dua orang observer. Penilaian diambil berdasarkan aspek keterampilan proses sains yaitu merumuskan masalah, mengidentifikasi masalah, merumuskan hipotesis, identifikasi variabel, melakukan percobaan, menganalisis data, menyimpulkan dan mengkomunikasikan yang kemudian akan dirata-rata pada setiap pertemuan. Berdasarkan hasil keterampilan proses sains siswa pada Tabel 10, diperoleh bahwa rata-rata aktivitas siswa pada kegiatan belajar I sebesar 72,24\%, kegiatan belajar II sebesar $83,75 \%$, dan kegiatan belajar sebesar III $88,75 \%$, dengan rata-rata keseluruhan $81,58 \%$. Dari data hasil observasi juga didapatkan bahwa keterampilan proses sains siswa juga meningkat dari tiap kegiatan belajar. Berdasarkan rata-rata keseluruhan keterampilan proses sains siswa dapat dikategorikan "Sangat Baik" Dari hasil observasi, diketahui juga bahwa skor tertinggi 
sampai skor terendah keterampilan proses sains yaitu menyimpulkan (86,38\%), bereksperimen $(84,86 \%)$, analisis data (84,58\%), mengomunikasikan (83,61\%), merumuskan hipotesis $(83,47 \%)$, merumuskan masalah $(80,14 \%)$, mengamati $(77,36 \%)$, dan yang terendah yaitu identifikasi variable (72,22\%).

Penilaian kemampuan berpikir kritis siswa dilakukan dengan menggunakan lembar observasi yang dilakukan oleh dua orang observer serta dengan test evaluasi dan uji kompetensi seperti pada hasil belajar siswa pada ranah kognitif, pembuatan soal berpikir kritis merujuk pada aspek berpikir kritis dari Facione (2011). Data kemampuan berpikir kritis yang diperoleh pada tahap uji coba besar meliputi enam aspek antara lain fokus pada sebuah pertanyaan, mengajukan dan menjawab pertanyaan klarifikasi, mengobservasi dan mempertimbangkan hasil observasi, membuat induksi dan mempertimbangkan induksi, melakukan evaluasi percobaan, memutuskan sebuah tindakan dan berinteraksi dengan orang lain. Data kemampuan berpikir kritis siswa dapat dilihat pada Tabel 11.

Berdasarkan Tabel 11. diketahui bahwa rata-rata kemampuan berpikir kritis siswa pada kegiatan belajar I sebesar 81,30, kegiatan belajar II sebesar 86,72 dan kegiatan belajar III sebesar 88,80. Dari hasil observasi, diketahui bahwa rata-rata skor tertinggi sampai skor terendah kemampuan berpikir kritis yaitu fokus pada pertanyaan (95,41\%), mengobservasi dan mempertimbangkan hasil observasi $(92,08 \%)$, berinteraksi dengan orang lain $(91,25 \%)$, membuat induksi dan mempertimbangkan induksi (89,17\%), mengajukan dan menjawab pertanyaan klasifikasi $(88,75 \%)$, mengevaluasi percobaan $(82,5 \%)$, dan skor terendah yaitu memutuskan sebuah tindakan (82,5\%). Dari hasil observasi ini diketahui bahwa modul sangat efektif untuk merangsang siswa dalam merancang sebuah pertanyaan dalam proses pembelajaran. Meskipun demikian, berdasarkan hasil observasi untuk setiap kali pertemuan menunjukkan bahwa hasil kemampuan berpikir kritis siswa selalu mengalami kenaikan yang memiliki kategori "Sangat
Baik". Hilal Aktamis dan Omer Ergin (2008) mengungkapkan bahwa keterampilan proses sains dapat meningkatkan kemampuan berpikir kritis siswa, sikap sains dan peningkatan kemampuan akademik.

Setelah dilakukan pembelajaran menggunakan modul elektronik berbasis keterampilan proses sains pada materi dinamika gerak, dilakukan observasi pada akhir kegiatan belajar III untuk mengetahui peningkatan motivasi belajar siswa. Tabel 12 menunjukkan perbandingan antara motivasi awal dan hasil observasi siswa setelah pembelajaran menggunakan modul elektronik berbasis keterampilan proses sains.

Nilai rata-rata motivasi belajar siswa sebelum pembelajaran sebesar $73,86 \%$, sedangkan nilai rata-rata motivasi belajar siswa setelah pembelajaran menggunakan modul sebesar 94,68\%. Dari hasil analisis didapatkan bahwa hampir semua aspek dalam motivasi belajar meningkat setelah diberi pembelajaran menggunakan modul elektronik pembelajaran Fisika berbasis keterampilan proses sains. Hasil ini sesuai dengan penelitian yang dilakukan oleh Widi Hariyanto (2012) yang menyatakan bahwa media pembelajaran berbasis IT dapat meningkatkan motivasi belajar siswa.

Setelah tahap uji besar selesai dilaksanakan, siswa diberi angket untuk mengetahui tingkat keefektifan modul. Berdasarkan Tabel 13 dapat disimpulkan skor rata-rata untuk indikator perhatian siswa adalah $99,3 \%$, skor rata-rata untuk indikator Keterkaitan adalah $95,7 \%$, skor rata-rata untuk indikator keyakinan adalah 95,0\%, dan skor rata - rata untuk indikator kepuasan $97,9 \%$. Total rata-rata keseluruhan adalah $97 \%$ termasuk dalam kategori "Sangat Baik".

Berdasar hasil uji besar, diperoleh saran dan masukan siswa terhadap modul Fisika berbasis keterampilan proses sains. Data menunjukkan modul yang digunakan pada uji besar tidak perlu diperbaiki karena menurut pendapat siswa modul elektronik Fisika yang digunakan sudah baik dari segi visual, materi, gambar, keterbacaan, dan soal yang digunakan. Hasil penelitian ini sesuai dengan penelitian yang dilakukan oleh Riduwan (2010) yang 
menghasilkan bahwa modul fisika berbasis keterampilan proses sains direspon sangat positif oleh siswa pada kelompok besar.

Hasil tanggapan siswa terhadap modul sudah baik sehingga tidak perlu dilakukan perbaikan dan layak untuk digunakan, selanjutnya produk modul didesiminasi dan implementasikan ke sekolah di Kota Surakarta.

\section{Tahap Diseminasi (Disseminate)}

Diseminasi dan implementasi dilakukan untuk memperkenalkan produk modul ke sekolah SMA/MA di Kota Surakarta. Data diseminasi dan implementasi berupa tanggapan, saran, dan masukan dari guru Fisika mengenai modul dan diharapkan modul Fisika berbasis keterampilan proses sains materi dinamika gerak dapat diterapkan sebagai bahan ajar baru.

Hasil kuesioner tahapan diseminasi dan implementasi produk oleh lima guru Fisika di Kota Surakarta yang ditunjukkan pada Tabel 14 diperoleh rata-rata sebesar 3,93 untuk aspek isi modul. Untuk aspek metode penyajian, bahasa, ilustrasi, kelengkapan dan aspek fisik sebesar 4,00. Untuk aspek keterlaksanaan sebesar 3,50. Dalam tahap keterlaksanaan ini tidak mencapai nilai 4 karena menurut guru masih perlu informasi alokasi waktu yang jelas tentang tahapan-tahapan keterampilan proses yang ada didalam modul. Berdasarkan masukan tersebut, guru diberi RPP yang digunakan dalam mengaplikasikan modul. Secara keseluruhan, data tahapan diseminasi dan implementasi produk dari para guru Fisika mempunyai rata-rata dari keseluruhan aspek sebesar 3,92 dikategorikan "Sangat Baik".

\section{Kesimpulan dan Rekomendasi}

Kesimpulan yang diperoleh berdasarkan hasil penelitian ini adalah:

1. Modul elektronik Fisika telah kembangkan dengan mengintegrasikan keterampilan proses sains untuk meningkatkan kemampuan berpikir kritis dan motivasi belajar siswa. Tahapan keterampilan proses sains yang

$\begin{array}{lr}\text { dimunculkan } & \text { dalam } \begin{array}{r}\text { modul } \\ \text { meliputi }\end{array} \\ \text { merumuskan } & \text { masalah, } \\ \text { merumuskan } & \text { hipotesis, } \\ \text { mengidentifikasi } & \text { variabel, } \\ \text { melakukan } & \text { eksperimen, } \\ \text { menganalisis } & \text { data, } \\ \text { menyimpulkan } & \text { dan }\end{array}$

mengomunikasikan.

Keseluruhan tahapan keterampilan proses sains ini masuk dalam tiap-tiap tahapan kegiatan belajar. Aspek berpikir kritis yang terdapat didalam modul diantaranya: fokus pada pertanyaan, mengobservasi dan mempertimbangkan hasil observasi, berinteraksi dengan orang lain, membuat induksi dan mempertimbangkan induksi, mengajukan dan menjawab pertanyaan klasifikasi, mengevaluasi percobaan, dan skor terendah yaitu memutuskan sebuah tindakan. Modul elektronik ini juga digunakan untuk meningkatkan motivasi belajar siswa. Aspek motivasi belajar siswa yang terdapat didalam modul diantaranya adalah: tidak cepat bosan pada tugas rutin, menunjukkan minat, tidak mudah melepas hal yang diyakini, senang bekerja mandiri, ulet dalam menghadapi kesulitan, dapat mempertahankan pendapatnya, tekun dalam menghadapi tugas, dan senang mencari dan memecahkan masalah soal-soal.

2. Modul dikategorikan baik karena telah melalui beberapa uji kelayakan. Berdasarkan uji kelayakan modul memiliki kategori layak digunakan, yang didukung dengan hasil perhitungan menunjukkan ratarata 3,80 lebih besar dari nilai minimum kelayakan 3,78. Hasil 
validasi oleh ahli materi pada komponen kelayakan isi dan kelayakan bahasa memiliki kategori sangat baik dengan nilkai rata-rata 3,85 . Hasil validasi oleh ahli media pada komponen kelayakan penyajian dan kegrafikan menunjukkan kategori sangat baik dengan nilai rata-rata 3,84. Hasil validasi oleh guru Fisika menunjukkan kategori sangat baik. Hasil validasi oleh peer review menunjukkan kategori sangat baik dengan nilai ratarata 3,72. Modul mendapatkan kategori respon baik dari siswa setelah menggunakan modul dalam proses pembelajaran. Hasil angket respon siswa yang terdiri dari 4 aspek menghasilkan kategori sangat baik dengan persentase rata-rata sebesar 3,85. Hasil disseminate yang dilakukan pada 5 sekolah di kota Surakarta menghasilkan modul dengan kategori sangat baik, didukung dengan hasil nilai rata-rata sebesar 3,92.

3. Hasil penelitian dan pengembangan modul Fisika berbasis keterampilan proses sains efektif meningkatkan kemampuan berpikir kritis siswa. Efektivitas modul didasarkan atas hasil perhitungan $\mathrm{N}$-gain yang ditinjau dari kenaikan hasil tes kognitif dan kemampuan berpikir kritis siswa sebesar 0,67 pada kelas sampel dan 0,59 pada kelas kontrol yang dikategorikan "sedang". Hasil signifikansi yang diperoleh berdasarkan uji $\mathrm{t}$ berpasangan sebesar $\mathrm{p}=0,000$, yang berarti terdapat perbedaan yang signifikan antara nilai hasil belajar kognitif antara kelas sampel dan kelas kontrol.
Berdasarkan hasil tersebut dapat disimpulkan bahwa modul fisika berbasis keterampilan proses sains pada materi dinamika gerak efektif dalam meningkatkan kemampuan berpikir kritis siswa.

4. Pengembangan modul elektronik Fisika berbasis keterampilan proses sains ini dinilai efektif meningkatkan motivasi belajar siswa. Hal tersebut dapat dilihat dari kenaikan nilai rata-rata peningkatan motivasi siswa kelas sampel yang menggunakan modul elektronik Fisika berbasis keterampilan proses sains yaitu 94,68. Nilai rata-rata ini telah meningkat daripada motivasi belajar awal siswa sebelum dilakukan proses kegiatan pembelajaran dengan menggunakan modul yang nilai rata-ratanya sebesar 73,86. Hasil uji statistik menunjukkan nilai signifikansi sebesar 0,027 lebih rendah dari taraf signifikansi $\alpha$ $=0,05$ sehingga dapat disimpulkan bahwa motivasi belajar siswa menggunakan modul Fisika berbasis keterampilan proses sains lebih baik dari pembelajaran konvensional.

\section{Daftar Pustaka}

Aktamis, Hilal dan Omer E. (2008). The Effect Of Scientific Process Skills Education On Students' Scientific Creativity, Science Attitudes And Achievements. Asia-Pacific Forum on Science Learning and Teaching vol. 9, hlm.1-4.

Arief S. Sardiman, et. al. (2010). Media Pendidikan. Jakarta: PT Rajagrafindo Persada. 
Aydinli, Emek, et. al. (2011). Turkish Elementary School Students' Performance on Integrated Science Process Skills. Procedia Social and Behavioral Sciences. Vol.15. hlm. 34693475 .

Dimyati, Mudjiono. (2013). Belajar \& Pembelajaran. Jakarta: Rineka Cipta.

Hake, R. (1998). Interactive-engagement methods in introductory mechanics courses. Diperoleh tanggal 7 September 2015, dari sumber online.

Hilal Aktamis dan Omer E. (2008). The Effect Of Scientific Process Skills Education On Students' Scientific Creativity, Science Attitudes And Achievements. Asia-Pacific Forum on Science Learning and Teaching. vol. 9: 1-4.

Ince, A.E., Guven, E., and Aydogdu, M. (2010). Effect of Problem Solving Method on Science Process Skills and Academic Achievement. Journal of Turkish Science Education, vol. 7 (4). Hlm. 13-25.

Keil, Chris, et. al. (2009). Improvements in Student Achievement and Science Process Skills Using Environmental Health Science Problem-Based Learning Curricula. Electronic Journal of Science Education. Vol.13.(1).

Lidy Alimah, Eko Setyadi. (2013). Studi tentang pengembangan modul fisika pada pokok bahasan listrik dinamis berbasis domain pengetahuan sains untuk mengoptimalkan Mind-on Siswa. Jurnal Radiasi Universitas Muhamadiyah Purworejo. vol.3. no. 1.

Pan, Guirong, et. al. (2010). A Survey on English Learning Motivation of Students in Qingdao Agricultural University. Journal of Language Teaching and Research. Vol.1(2), 151-156. ISSN. Hlm. 1798-4769.

Peraturan Pemerintah No. 19 tahun 2005. Standar Nasional Pendidikan. Jakarta: Peraturan Pemerintah Nasional.

Peraturan Pemerintah No. 32 Tahun 2013. Perubahan Standar Nasional Pendidikan. Jakarta: Peraturan Pemerintah Nasional.
Permendiknas No. 41 Tahun 2007. Standar Proses. Jakarta: Peraturan Pemerintah Nasional.

Rauf, Abd Amnah Rose, et. al. (2013). Inculcation of Science Process Skills in a Science Classroom. Canadian Center of Science and Education, Asian Social Science: Vol.9(8), ISSN 1911-2017 E-ISSN. Hlm.1911-2025.

Sardiman. (2012). Interaksi dan Motivasi Belajar Mengajar. Jakarta: Rajawali Pers.

Sugianto, Dony dkk. (2013). Modul Virtual: Multimedia Flip Book Dasar Teknologi Digital. INVOTEC, Vol. IX No.2 Agustus 2013 p. $110-116$

Sugiyono. (2012). Metode Penelitian Pendidikan. Bandung : Alfabeta.

Suharsimi, Arikunto. (2010). Prosedur Penelitian Suatu Pendekatan Praktik. Jakarta : PT. Rineke Cipta.

Tim Penyusun. (2015). Panduan Penulisan Tesis. Surakarta: UNS

Thiagarajan, Sivasailam, DS, Semmel Melvyn. (1974). Instruction Development for Training Teachers of Exceptional children. Minneapolis: Indian University.

Valentino, Catherine. (2000). Developing Science Skills. Houghton Mifflin Company. Diperoleh tanggal 31 Agustus 2015,dari sumber online.

Widi Hardiyanto. (2012). Pemanfaatan Media Pembelajaran Berbasis Macromedia Flash 8 Guna Meningkatkan Motivasi Belajar Siswa pada Poko Bahasan Sifat Mekanik Bahan. Radiasi. Vol.1: 1.

Wiyoko, Tri dkk. 2014. Pengembangan Media Pembelajaran Fisika Modul Elektronik Animasi Interaktif untuk Kelas XI SMA Ditinjau dari Motivasi Belajar Siswa. Jurnal Pendidikan Fisika, Vol. 2 No. 2 Juni 2014 p.11-15

Yudhi Munadi. (2010). Media Pembelajaran. Jakarta: Gaung Persada (GP) Press.

Yuliani, H, Widha Sunarno dan Suparmi. (2012). Pembelajaran Fisika Dengan Pendekatan Keterampilan Proses Dengan Metode Eksperimen Dan Demonstrasi Ditinjau 
JURNAL INKUIRI

ISSN: 2252-7893, Vol. 6, No. 3, 2017 (hal 61-76)

http://jurnal.uns.ac.id/inkuiri

Dari Sikap Ilmiah Dan Kemampuan

Analisis. Jurnal Inkuiri Universitas Sebelas Maret Surakarta. vol. 1. Hlm. 207-216. 


\section{JURNAL INKUIRI}

ISSN: 2252-7893, Vol. 6, No. 3, 2017 (hal 61-76)

http://jurnal.uns.ac.id/inkuiri 